\title{
Plads til opposition?
}

\section{Egyptisk tv i Istanbul}

Siden 2013 har egyptiske tv-kanaler etableret sig i Istanbul, hvorfra de har kritiseret og gjort grin med det egyptiske regime. Men hvad er deres mulighed for opposition som del af en egyptisk diaspora?

af ЕНАВ GALAL

$\mathrm{E}$ nhver der omtaler os i de tv-stationer i udlandet, - jeg sværger ved gud, de skal alle sammen komme til at betale for det (klapsalver fra salen). Alle skal betale for det. Jeg sværger ved gud, at alle skal betale for det.» ${ }^{1}$

Ordene er den egyptiske præsident, Abd al-Fatah el-Sisis, og faldt under ungekonferencen National Youth Conference d. 16. maj 2018. Sisi blev bedt om at komme med en kort kommentar, der tog knap en time og endte med ovennævnte angreb på udenlandske tv-stationer. Det er egyptiske regimekritiske medier, der befinder sig i udlandet, som Sisi her refererer til. Selv om det ikke er første gang, Sisi adresserer oppositionsmedier uden for Egypten, ${ }^{2}$ er udtalelsen fra 2018 særlig graverende ifølge The Arab Media Monitor på grund af den direkte trussel sammenholdt med de ikke nærmere definerede sanktioner. ${ }^{3}$ Siden Sisi som chefen for militærets efterretningstjeneste indtrådte i den egyptiske militærkomite i 2011, har han jævnligt i taler og under møder med hæren og journalister fremhævet mediernes rolle og store indflydelse. ${ }^{4}$ Selv om etablerede egyptiske massemedier i Egypten må siges at være 100 procent loyale over for Sisi og hans regime, ${ }^{5}$ har han gang på gang kritiseret de egyptiske medier i Egypten for ikke at udføre deres arbejde ordentligt eller støtte ham og statens mission. ${ }^{6}$ Han har ydermere givet udtryk for at misunde den egyptiske præsident Nasser for at have haft medierne på sin side. ${ }^{7}$ Det egyptiske regimes fors $\emptyset \mathrm{g}$ på at stække regimekritiske medier og deres ansatte i udlandet skal derfor ikke ses som tomme trusler, men afspejler en udvikling, som jeg i det følgende vil belyse dele af gennem studiet af egyptiske medier i Istanbul.

Siden det egyptiske militærkup og Sisis magtovertagelse i 2013 har en række egyptiske medier etableret sig uden for Egypten med 


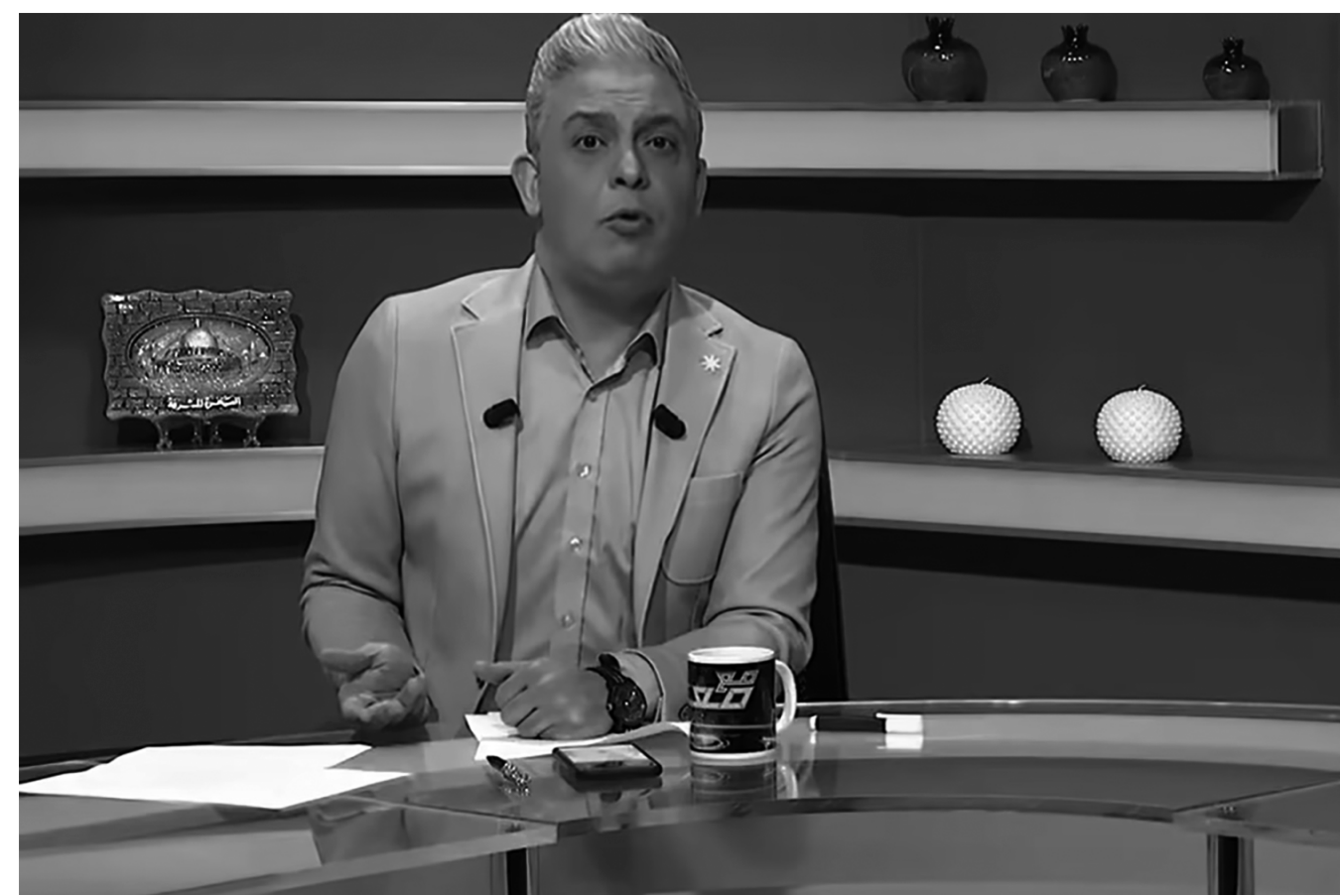

Moataz Matar var aktiv under den egyptiske motstand i 2011 og forlod landet efter 2013 på grund af den politiske situation.

Istanbul som centrum for et skiftende antal egyptiske regimekritiske tv-kanaler. ${ }^{8}$ Disse kanaler er således resultatet af de politiske forandringer og konflikter, der fulgte i kølvandet på kuppet i 2013. Undertrykkelsen af oppositionelle medier og aktivister i Egypten har været en drivkraft for etableringen af dette diasporiske rum for mobilisering til forandring. Et afgørende element i denne udvikling har været, at ikke blot medier men også politiske aktivister på tværs af liberale og islamistiske positioner har søgt væk fra Egypten, og at Tyrkiet har budt dem velkommen. Mens kanalerne repræsenterer forskellige ideologiske standpunkter, har de delt et fælles narrativ om det nuværende egyptiske regimes illegitimitet og undertrykkelse ved blandt andet at udstille regimets inkompetence og dobbeltmoral. Det har været med til at skabe og opretholde et transnationalt, egyptisk, regimekritisk rum, som den egyptiske diaspora synes at have bredt kendskab til, uanset hvad de ellers synes om disse tv-kanaler. Et oppositionelt rum, som det egyptiske regime på flere måder har forsøgt at stække.

I denne artikel belyser jeg de regionale politiske, diasporiske og medieinstitutionelle sammenfiltringer i en bestræbelse på at forstå de Istanbulbaserede, egyptiske tv-kanalers mulighed for regimekritik og opposition. Mit særlige fokus på tv skal skærpe opmærksomheden på de betingelser medieinstitutionen er underlagt i modsætning til sociale medier, der agerer på andre betingelser, selv om også de i høj grad forsøges begrænset af lande som f.eks. Egypten.

Artiklen bygger på et omfattende empirisk arbejde, der inkluderer mediemateriale fra de omtalte medier i Istanbul, andet mediemateriale, der belyser den aktuelle politiske situation $\mathrm{i}$ Egypten, samt kvalitative interviews med egyptere 
og egyptisk mediepersonel i Tyrkiet. Interviewene havde fokus på baggrund og motiv for etablering af og engagement i medier i Tyrkiet.

\section{Et transnationalt og diasporisk perspektiv}

Inden Istanbul blev centrum for egyptiske regimekritiske medier, var London stedet, hvor flest arabiske, politiske oppositionsgrupper og regimekritiske medier slog sig ned, heriblandt tvstationerne al-Hiwar Tv, al-Araby Tv, al-Magharbia og ANN. Inden for den trykte presse har aviserne alAraby al-Jadid og al-Quds al-Arabi haft base i London, mens Doha med tv-stationen al-Jazeera længe har udgjort den arabiske undtagelse, hvad angår kritiske medier. De London- og Dohabaserede medier er ikke decideret egyptiske, men dækningen af den politiske situation i Egypten har fyldt meget, ligesom mange studieværter, journalister og teknikere fra disse medier har egyptisk baggrund.

Ved at etablere sig uden for Egypten har de regimekritiske medier i princippet fortsat kunne kritisere det egyptiske regime, uden at den egyptiske stat har haft mulighed for direkte at sanktionere dem. Således har adskillige egyptiske regime-kritiske tv-kanaler siden juli 2013 sendt fra lande som London, Qatar, Sudan, Libanon og Tyrkiet i forsøget på at opnå transnational indflydelse på den arabiske offentlighed. Flere har dog måtte lukke igen på grund af enten finansielle problemer eller egyptisk politisk pres på værtslandet. Her har kanalerne i Istanbul - indtil for nyligt - skilt sig ud i kraft af den tyrkiske stats utvetydige støtte.

I Istanbul er de mest fremtrædende tv-kanaler i 2021: al-Watan Tv, al-Sharq Tv og Mekameleen Tv. De deler en kritisk tilgang til det autokratiske egyptiske regime og $\emptyset$ nsker at mobilisere politisk opposition blandt egyptere (og arabere) inden for såvel som uden for Egypten og Mellemøsten. Udover selv at være en del af den egyptiske diaspora, henvender disse medier sig også til selvsamme diaspora og er dermed et klassisk eksempel på eksilmedier, der tilbyder et rum for mobilisering til forandring af hjemlandet. ${ }^{9}$

Sammenlignet med forskning om egyptiske revolutionære og regimekritiske medier i årene op til og umiddelbart efter revolutionen i 2011, er forskningen i egyptiske regimekritiske mediers rolle siden 2013 mangelfuld. Sociale medier $1 \varnothing b$ med den helt store opmærksomhed i 2011, og forskningens fokus var primært på mobilisering af egyptere i Egypten. ${ }^{10}$ Kun få studier har unders $\varnothing$ gt politisk mobilisering af egyptere uden for Egypten i forbindelse med 2011-revolutionen, ${ }^{11}$ ligesom der også har været minimal interesse for at undersøge de traditionelle medier, herunder pressen, for mobiliseringspotentiale. ${ }^{12}$ Også $\mathrm{i}$ årene efter 2011 har fokus været på onlinemedier, bl.a.i forbindelse med et studie af Det Muslimske Broderskabs mediestrategi efter fjernelsen af den daværende, demokratisk valgte, egyptiske præsident, Mohamed Morsi i 2013. ${ }^{13}$

Siden da har det, som nævnt, været det egyptiske regimes politik så vidt muligt at begrænse de egyptiske mediers frihed til at kritisere regimet, hvilket har fået mange aktivister og oppositionspolitikere til at flygte til udlandet og herfra etablere eller bidrage til kritiske medier. Iblandt de begrænsede studier af egyptiske regimekritiske medier i diaspora er et enkelt studie, der undersøger, hvordan enkeltindivider, henholdsvis en saudisk og egyptisk aktivist, gennem sociale medier fors $\emptyset$ ger at mobilisere en opinion i deres respektive oprindelseslande. ${ }^{14}$ Til gengæld har de egyptiske tv-kanaler, der siden 2013 er blevet etableret i Istanbul, ikke fået megen forskningsmæssig opmærksomhed. Det vil denne artikel bidrage til at råde bod på ved at belyse den regimekritiske rolle, som disse tv-kanaler i Istanbul har påtaget sig siden 2013.

Til at belyse de egyptiske kanalers rolle som po- 


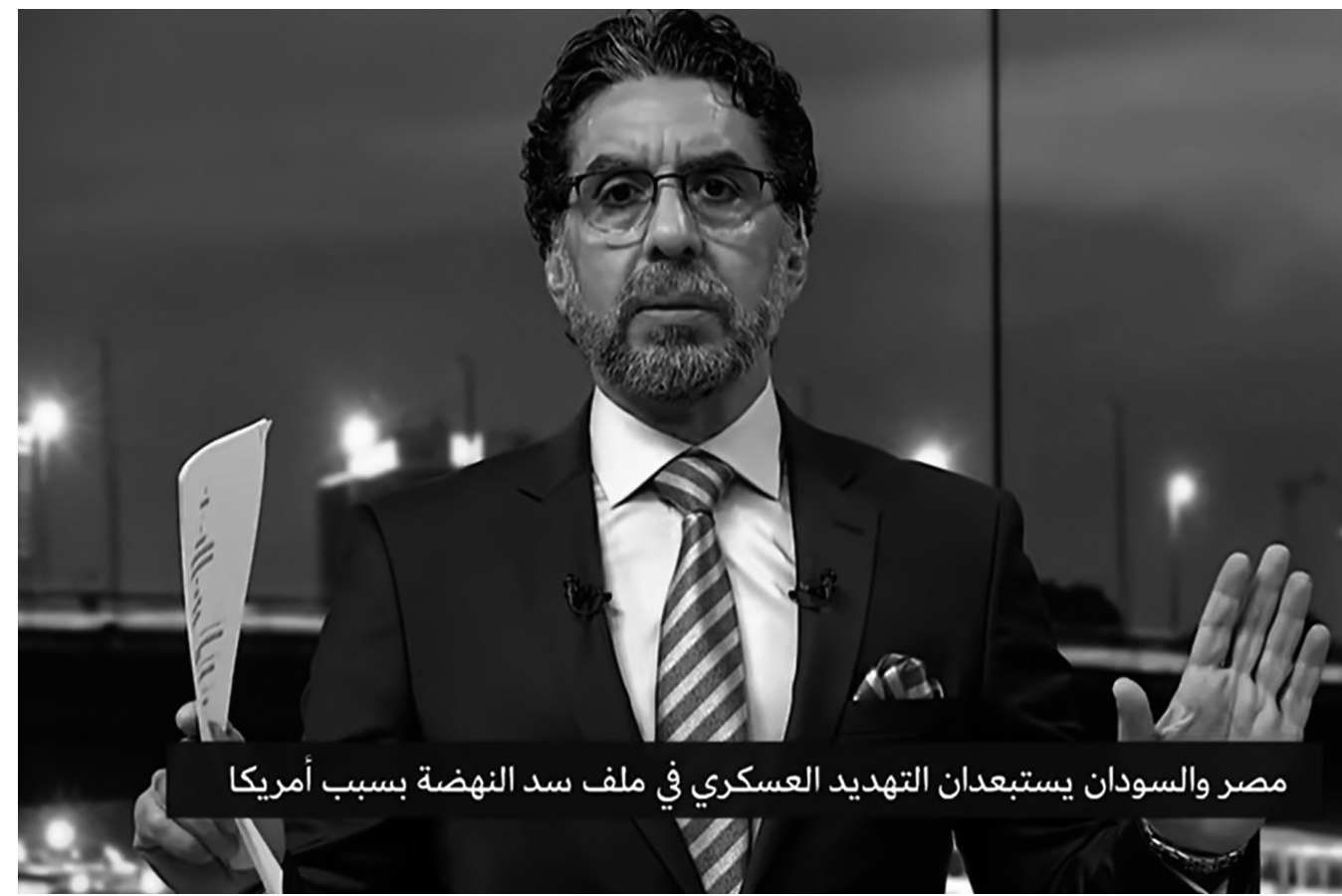

Mohammed Nasser er studievært på Mekameleen Tvs viktigste program: Masr en-Naharda (Egypten i dag).

litisk mobiliserende i en diasporisk kontekst forstår jeg mediedynamikker og konflikter som «amplifying, framing, performative and co-constructed». ${ }^{15}$ Samtidig kommer kanalernes mediering af diasporiske narrativer til at afspejle en «transnationalisering» af hverdagslivet, hvor medieproduktion og mediebrug overskrider nationale grænser ${ }^{16}$ De transnationale og diasporiske narrativer fungerer ifølge Fiona $B$. Adamson som én af tre centrale måder, hvorpå diasporaer fors $\varnothing$ ger at mobilisere ligesindede med henblik på at ændre den politiske tilstand i oprindelseslandet. Via placeringen i udlandet tilbydes alternative narrativer, der udfordrer hjemlandsregimets hegemoniske diskurs. En anden måde at mobilisere til forandring er at alliere sig med statslige og ikke-statslige aktører for at $\emptyset$ ge presset på hjemlandsregimet, mens en tredje måde er at overføre ressourcer til aktører i hjemlandet i forsøget på at skubbe til magtbalancen. ${ }^{17}$ Med et diasporisk perspektiv sættes således fokus på, hvordan mediebrug forbinder sig til både emotionelle, nationale tilhørsforhold og organisatoriske strukturer ${ }^{18} \mathrm{En}$ - i dette tilfældeegyptisk diaspora skal hverken forstås som et på forhånd givet «essentialiseret» fællesskab ${ }^{19}$ eller en fortrinsvis teknologi-drevet cyber public. ${ }^{20}$ I stedet undersøges den diasporiske mediepraksis i samspil med politisk konflikt. De regimekritiske Istanbulkanalers primære formål er da også gennem alternative narrativer at udfordre den egyptiske stats fremstilling af de politiske konflikter og situationen i Egypten. En forudsætning herfor har imidlertid været alliancen med den tyrkiske stat.

\section{Medieudviklingen efter 2011}

Et element i 2011-revolutionens succes var den forudgående medieudvikling, hvor internet, satellittv og sociale medier, i kombination med en delvis liberalisering af egyptiske medier gennem 
1990erne og 2oooerne, havde medvirket til skabelsen af et varieret og transnationalt medielandskab. Det gjorde det muligt for nye politiske stemmer at udfordre eksisterende politiske værdier og den autoritative egyptiske stat.21

Efter revolutionen i 2011 stod både aktivistiske medier og mainstreammedier over for en ny virkelighed, hvor grænser for mediefrihed ikke blev fastlagt eller beskyttet, som medierne havde været vant til. Det tilsyneladende fravær af en entydig magt gav de egyptiske borgere nye muligheder som opinionsdannere. Derfor fremsatte egypterne under og efter oprøret i 2011 forskellige meninger, der gradvist skabte en mere forskelligartet og kritisk offentlighed end tidligere set. ${ }^{22}$ Perioden fra 2011 til juni 2013 er tæt på at være en gylden æra for de egyptiske medier. For første gang siden den egyptiske selvstændighed i 1952 kunne egypterne i nationale medier se og læse udtalelser og kritik fra repræsentanter fra alle dele af det egyptiske samfund. Selv om etablerede medieinstitutioner var domineret af liberale og verdslige politiske synspunkter, blev også islamister - såsom aktivister fra Det Muslimske Broderskab og diverse Salafi-repræsentanter inviteret med i forskellige talkshows og debatter for at bidrage med deres synspunkter. ${ }^{23}$ Islamisterne fik dog aldrig samme taletid som de liberale, ligesom deres medier ikke kunne konkurrere med antallet af liberale medieplatforme.

Den 3. juli 2013 blev præsident Mohamed Morsi fjernet fra magten ved et militærkup. I de liberales øjne gjorde Morsis forbindelser til Det Muslimske Broderskab ham til fortaler for en islamisk stat, og det nye egyptiske regime - under en stærk militærleder - blev derfor set som en nødvendig garant imod en truende islamisering, som blev omtalt som Akhwanit ad-Dawla (at gøre landet til Det Muslimske Broderskab). Ikke overraskende blev Muslimske Broderskabs- og andre islamistiske medier lukket efter kuppet, og ak- tivister fra Broderskabet blev fængslet. ${ }^{24}$ De gradvise begrænsninger af alle medier og kritiske stemmer var mere uforudsete og ramte også liberale aktivister, der aktivt havde mobiliseret via sociale medier og været $\mathrm{i}$ front under oprøret i 2011, som f.eks. Kefaya- og 6. april-bevægelsen. ${ }^{25}$

Siden 2014 har det egyptiske regime således forsøgt at stoppe al kritik, både inden- og udenlands. En række love er blevet vedtaget for at begrænse medierne i Egypten, og forskellige medieudvalg i form af Supreme Council for Media Regulation, the National Press Authority og the National Media Authority er blevet nedsat for at holde $\varnothing$ je med pressen og medierne. ${ }^{26}$ Som det fremgår af Sisis udtalelser, forsøger det egyptiske regime ligeledes at begrænse egyptiske regimekritiske medier i diaspora. De indenlandske egyptiske medier og politikere har således ført hetz mod de kritiske diasporamedier for at miskreditere deres troværdighed som kilde. Andre måder at fors $\emptyset$ ge at begrænse regimekritiske mediers og i særdeleshed Istanbulkanalernes indflydelse har været, at ejerne af f.eks. en satellit har udsat kanalerne for jamming eller lukning. SaudiArabien har således en betydelig ejerandel $\mathrm{i}$ Arabsat, og den egyptiske stat ejer Nilesat. Det er derfor ikke overraskende, at al-Jazeera ikke kan ses i Egypten via Nilesat. Endelig har det egyptiske regime fors $\emptyset \mathrm{gt}$ at tvinge regimekritiske kanaler til at stoppe deres kritik ved at lægge pres på kanalernes medarbejdere gennem chikane eller fængsling af deres familiemedlemmer i Egypten.

I forhold til udlandet har det egyptiske regime kontaktet og lagt pres på kritiske mediers værtslande, som f.eks. Storbritannien, Frankrig, Tyskland, USA, Tyrkiet og Qatar, med anklager om disse mediers opfordring til vold, drab, had og terror. Samtidig er forsøg på at styre regimekritiske medier i udlandet generelt blevet en del af en regional politik. Det viste sig f.eks. da Saudi-Arabien, Bahrain, FAE og Egypten efter fælles overenskomst 
boykottede Qatar fra juni 2017 til januar 2021. En af begrundelserne for denne boykot var, at Qatar holdt hånden over tv-kanalen al-Jazeera, som ikke holdt sig tilbage fra at kritisere de pågældende landes styrer. ${ }^{27}$

På samme måde har egyptiske regimekritiske mediers tilstedeværelse i Istanbul været en torn i $\emptyset$ jet på det egyptiske regime og et element i den konflikt, der siden 2013 har eksisteret og næsten stoppet al diplomatisk forbindelse mellem det tyrkiske og det egyptiske styre. Den udløsende faktor var den tyrkiske præsident, Recep Tayyip Erdogans beskyldninger mod Sisi for at være hovedarkitekten bag militærkuppet i juli 2013. Erdogan fordømte både kuppet og massakren på Ra'ba al-'Adawiya pladsen i Kairo i august 2013, hvor støtter af Det Muslimske Broderskab efter seks ugers fredelig sit-in demonstration til st $\varnothing$ tte for Morsi blev fjernet med magt af de egyptiske sikkerhedsstyrker med mange døde og sårede til følge. Fordømmelsen skal på den ene side ses i lyset af, at Erdogans parti, Retfærdigheds- og Udviklingspartiet (AKP) beskriver sig selv som et moderat muslimsk parti, der generelt har bakket op om politisk islam. På den anden side har AKP som regeringsparti fors $\emptyset \mathrm{gt}$ at promovere Tyrkiet som et succesfuldt eksempel på økonomiske reformer og demokrati, som de arabiske lande kunne tage ved lære af. Således støttede AKP-regeringen opstandene i de arabiske lande i 2011 og derefter. ${ }^{28}$ Det var derfor ikke overraskende, at Tyrkiet bød den egyptiske diaspora og deres medier velkomne, hvoraf flere, om end langt fra alle, havde relationer til Det Muslimske Broderskab. Dermed kunne AKP opretholde billedet af sig selv som beskytter af islam, samtidig med at Tyrkiet - bl.a. over for Europa - kunne fremstå som et demokratisk sindet land og dermed en troværdig samarbejdspartner. At tyrkiske medier ikke har den samme mulighed for at kritisere den tyrkiske stat, ikke mindst efter er kupforsøg i 2016, kan ses som et udtryk for, at det ikke er mediefriheden i sig selv, som Tyrkiet $\emptyset$ nsker at fremme. I stedet er de arabiske regimekritiske medier i Istanbul en brik i Tyrkiets geo- og regionale politiske ageren.

I slutningen af 2020 begyndte Tyrkiet at nærme sig Egypten for at komme ud af den isolation, der havde sat landet uden for de østlige middelhavslandes politiske og $\varnothing$ konomiske aftaler. Som betingelse for at genoptage de diplomatiske forbindelser krævede Egypten, at alle egyptiske oppositionsmedier i Tyrkiet blev lukket. ${ }^{29}$ Resultatet var, at den tyrkiske stat ved udgangen af marts 2021 bad de tre egyptiske kanaler, Mekameleen Tv, al-Sharq TV og Watan Tv, om at «moderere deres kritik af Egypten», ${ }^{30}$ herunder dæmpe tonen i deres kritik, ikke mindst i kritikken af Sisi, samt forholde sig til den journalistiske etik. ${ }^{31}$ Mens de nationale, egyptiske medier hyldede udviklingen som en sejr, ${ }^{32}$ har flere egyptiske kommentatorer og embedsmænd krævet total stop for oppositionsmedier i Tyrkiet og krævet de oppositionsmedlemmer, der har en dom i Egypten og er bosat i Tyrkiet, udleveret. ${ }^{33} \mathrm{At}$ denne form for aftaler ikke er ensidige, viser sig ved, at de nationale, egyptiske medier i Egypten umiddelbart derefter er ophørt med at kritisere Erdogan, som de ellers har gjort siden 2013. ${ }^{34}$

Den megen energi, Egypten bruger på at begrænse de regimekritiske mediers indflydelse, kan tolkes som tegn på kanalernes relative succes. Som minimum afspejler regimets politik, at Egypten opfatter oppositionen i diaspora som en trussel mod landets stabilitet. Men hvad kendetegner egentlig disse kanaler?

\section{Egyptiske Istanbul-kanaler}

De egyptiske kanaler i Istanbul tilhører gruppen af arabiske oppositionsmedier, der er karakteriseret ved at være arabiskejede medier, at sende til arabiske seere på arabisk og hovedsageligt være interesseret $\mathrm{i}$ arabiske (primært egyptiske) an- 
liggender. Andre typer af arabiske medier i Tyrkiet er mere optaget af tyrkiske forhold, ligesom der er arabisk ejede medier, der sender på tyrkisk, og tyrkisk ejede medier, der sender på arabisk. ${ }^{35}$ Der er altså tale om et mangfoldigt arabiskorienteret medielandskab i Tyrkiet, hvor de egyptiske regimekritiske kanaler er karakteriseret ved deres mobiliserende agenda målrettet Egypten.

Blandt de tre tidligere omtalte kanaler, der dominerer Istanbul-scenen, er den første den Muslimske Broderskabskanal al-Watan TV (Nationen). Den anden er al-Sharq TV (Østen), der administreres af den velkendte egyptiske, liberale politiker Ayman Noor. Den tredje er Mekameleen TV (Vi vil fortsætte), der har liberale mediepersonligheder ansat men også yngre aktivister, som tidligere var medlemmer af Det Muslimske Broderskab. Blandt disse er nogen i opposition til Broderskabets etablerede lederskab, mens andre har støttet fraktionsgrupper under Broderskabet. En fjerde kanal, som også transmitterer fra Istanbul, er al-Da'wa TV (Missionen). Kanalen hører til Det Muslimske Broderskab, men på trods af Broderskabets oppositionsrolle i Egypten, er kanalen ikke på samme måde en regimekritisk kanal. Der er snarere tale om islamisk tv, der udelukkende har fokus på religiøse tematikker. Selv om kanalen og de islamiske lærde, der optræder heri, kan bruge kanalen til eksplicit eller implicit at skabe paralleller mellem den islamiske historie og den nuværende politiske situation i Egypten, vil jeg stadig betegne kanalen som islamisk snarere end regimekritisk. ${ }^{36}$

Al-Watan Tv, al-Sharq TV og Mekameleen Tv omtaler sig selv som et revolutionært rum, idet de kæmper for realiseringen af den egyptiske revolution, som blev påbegyndt i 2011. Kanalerne er eksempler på medier, som ikke blot dækker, men er dybt involveret $i$ og et resultat af en politisk konflikt i oprindelseslandet. Det har betydning for deres kommunikationsstrategier såvel som deres planlægning, organisering og mediepraksisser, og dermed for deres brugere, der mobiliseres i kraft af konflikten. ${ }^{37}$

Tilbuddet om alternative narrativer om Egypten udgør kernen i de egyptiske regimekritiske tvkanalers programflade i Istanbul. På overfladen ligner de regimekritiske kanalers varierede programflade andre mainstreamkanalers. De sender aktuelle egyptiske nyheder og programmer om politik, historie, kultur, religion, økonomi og sport. De viser også livsstilsprogrammer, madlavningsprogrammer, musikvideoer, tv-nyheder, talkshows, spillefilm og tv-serier, som oftest er indkøbt og ikke produceret af kanalerne selv. De dækker i mindre grad regionale og internationale nyheder. Derudover rapporterer de om og sender dokumentarfilm, der belyser det daglige liv i Egypten, og som ifølge kanalerne dokumenterer, hvordan det står til i det egyptiske samfund. Nogle programmer transmitteres live og giver seerne mulighed for at ringe ind og give udtryk for deres mening om et på forhånd defineret emne. Med ganske få undtagelser anlægger alle programmer et kritisk perspektiv på det egyptiske regime. Dette ses f.eks. i programmet om kvindespørgsmål, der politiserer og kritiserer den nuværende situation for den egyptiske kvindes hverdagsliv i Egypten.

Den primære genre, som især Mekameleen TV og al-Sharq TV er kendte for, er aftenens ofte langvarige talkshows. Et af disse er Alloo Mekameleen (Hello Mekameleen) med Ahmed Samir som vært. Samir var med til at starte Mekameleen TV efter at have været journalist og have undervist i historie $\mathrm{i}$ flere forskellige lande. I programmet ringer seerne ind for at diskutere og give udtryk for deres holdning til et aktuelt emne. Selv om de fleste er enige i kanalens politiske standpunkt, er der også plads til de modsatte. På al-Sharq Tv er Hisham Abdallah, en tidligere kendt egyptisk skuespiller, vært for programmet Ibn El-Balad (Folkets søn). Han tager i sit talkshow et aktuelt og brændende 


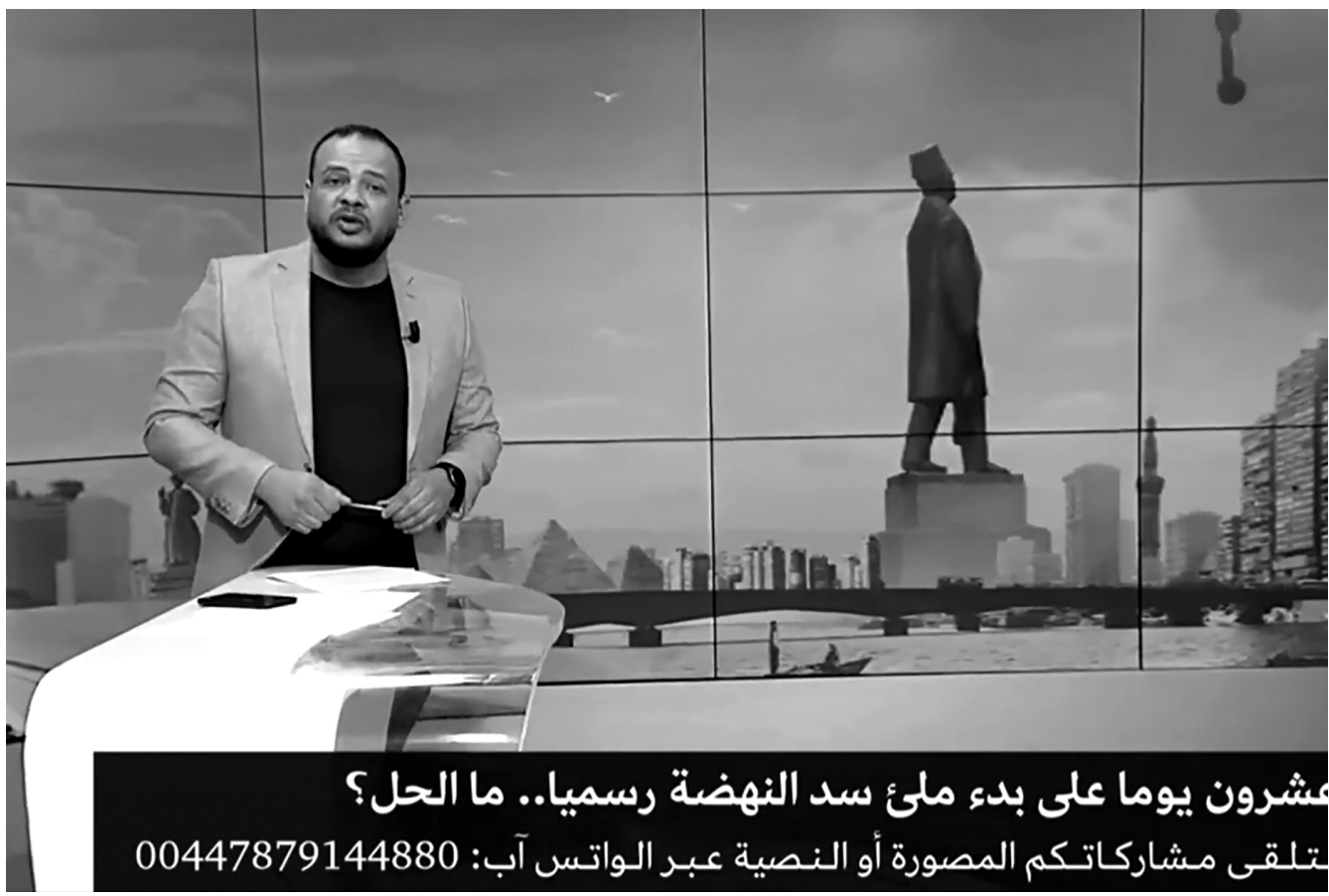

Ahmed Samir er vært for et program på Mekameelen der seerne ringer ind for at diskutere et aktuelt emne.

emne op til debat, samtidig med at han ofte henviser til egyptiske film og tv-serier. På Watan Tv er den karismatiske Nour al-Din Abd-al-Hafiz vært for programmet Asl al-Hikaya (Sagens kerne), der fremstår som én lang soloperformance. Abd-alHafizs politiske aktiviteter under og efter den egyptiske revolution i 2011 fik ham til at forlade sin mangeårige profession som ingeniør og gå ind i mediebranchen. Han var tv-vært på Misr25, som hørte til Det Muslimske Broderskab og sendte fra Egypten, indtil den samtidig med tre andre islamiske kanaler blev lukket den 2. juli 2013.38 Kanalens navn refererer til den 25. januar 2011, som betegner højdepunktet på den folkelige opstand, der endte med at vælte den daværende præsident Hosni Mubarak. To andre kendte studieværter er Muhammed Nasser og Moataz Matar, der begge har været vært for deres eget talkshow. Indtil for nylig var Matar studievært på talkshowet Ma'aa Moataz (Sammen med Moataz) på al-Sharq
TV, mens Nasser er studievært på Mekameleen TVs vigtigste program: Masr en-Naharda (Egypten i dag). I deres programmer angriber Nasser og Matar det egyptiske militærregime og kritiserer præsident Sisi, hans regering og parlament $\mathrm{i}$ kraftige vendinger. I deres dækning af brændende politiske emner er deres optræden karakteriseret ved at være konfronterende, overdreven og sarkastisk. Denne blanding af et brændende emne og en satirisk tilgang gør programmerne både uformelle og underholdende sammenlignet med mere formelle politiske diskussioner. Man kan således se studieværten fortælle hjerteskærende historier, hvor stemme, mimik og bevægelser sættes i spil, som om han stod på en teaterscene. Denne form for talkshow afhænger meget af studieværtens karisma og popularitet, snarere end af det specifikke programindhold. Det er derfor heller ikke overraskende, at netop disse to studieværter udover deres eget tv-program også har deres egen 
YouTube-kanal og er aktive på andre sociale medier. Det gælder også al-Hafiz på Watan Tv, ligesom det gælder Youssef Hussein på den Londonbaserede kanal al-Araby TV. Andre egyptiske YouTubere i diaspora er Ayat Oraby, Ahmed elBuhiri, Abdullah Elshrif og Aly Hussin Mahdy, som ikke er knyttet til noget etableret medie, men har millioner af seere. Uanset om vi taler om den ene eller anden form for YouTuber, bruger alle YouTube til at kritisere og opponere imod det nuværende egyptiske regime.

Ét aspekt er, at de egyptiske, regimekritiske kanaler i Tyrkiet forsøger at mobilisere egyptere i og uden for Egypten ved at tilbyde alternative narrativer. Men som Adamson ${ }^{39}$ også peger på, er et andet aspekt mobiliseringen af statslige og andre allierede. Som nævnt har Tyrkiet været en sådan allieret ind til foråret 2021. Men derudover kan man også anskue kanalernes ejere som

$$
\odot \odot \odot
$$

Det er svært at forudsige, hvorvidt de

kritiske stemmer også er stoppet, eller

om de er i stand til at finde nye

platforme for kritik.

$\odot \odot \odot$

sådanne allierede. Måske er det netop det mobiliserende aspekt, der gør, at ejerskabet af de regimekritiske kanaler i Istanbul generelt fremstår sløret. Baseret på interviews med kilder i Istanbul tyder alt dog på, at der er tale om investorer fra den arabiske Golf og egyptere i udlandet. Ofte ved hverken medarbejdere eller seere, hvem kanalens ejere er. Seerne giver dog ofte udtryk for kritik af udenlandske ejeres indflydelse på den redaktionelle linje.

En tredje måde at mobilisere alliancer er igennem brugen af såkaldte «borgerjournalister» i Egypten. Uden korrespondenter i Egypten er kanalerne afhængige af almindelige egyptere, og hvad der cirkuleres på sociale medier, for at kunne rapportere fra hjemlandet. En afhængighed der samtidig svækkes af almindelige egypteres frygt for regimets chikane, hvis man offentligt udtaler sig kritisk imod regimet. De manglende eller anonyme kilder svækker den journalistiske kvalitet. Det betyder til gengæld, at kanalernes dominerende narrativ tager afsæt i de egyptiske mainstreammediers fremstilling af regimet og situationen i Egypten og vender den på hovedet ved at udstille selvmodsigelser og absurditeter i regimets selvfremstilling.

\section{Eksilaktivisme i Istanbul}

Tv-kanalerne i Istanbul er ikke blot etablerede medieinstitutioner, men udgør også i sig selv diasporiske netværk for politisk mobilisering. En stor del af de ansatte på tv-kanalerne har selv forladt Egypten af politiske grunde efter 2013. I en forskningsrapport med titlen «Egypt's Political Exiles: Going Anywhere but Home» skriver Dunne og Hamzawy, at Egypten ikke tidligere har oplevet så stor en udvandring af politiske grunde som den, der har fundet sted siden 2013. ${ }^{40} \mathrm{I}$ sammenligning med de egyptere, der udvandrede i 1950-1970, er udvandringen siden 2013 karakteriseret ved en lang større mangfoldighed af identiteter, motiver, destinationer og oplevelser i eksil, samtidig med at flere tilsyneladende er yngre og mere veluddannede. En af årsagerne til denne mangfoldighed er ifølge Dunne og Hamzawy, at «far more groups are at serious risk in Egypt Islamists as well as Christians, liberals as well as leftists, artists as well as businesspeople, prominent intellectuals as well as scrappy activists - compared to the past, when fewer groups faced political or social persecution at any given time».41 I perioden 2011 til sommer 2013 opfordrede egyptiske islamister egyptere, der ikke kunne lide deres fremgang, til at udvandre til Canada eller USA. Efter militærkuppet i 2013 fik islamister at vide, at de kunne udvandre til Qatar eller Tyrkiet, 
hvis de ikke kunne lide det nye styre..$^{22}$ Denne binære opposition er dog for længst overhalet af en politisk virkelighed, hvor både islamister og liberalister siden begyndelsen af 2014 har mødtes i Istanbul. Dér har de delt oplevelsen af at være uønskede af det nye egyptiske regime, at leve i eksil og være modstandere af det nuværende egyptiske militærstyre.

De to tidligere omtalte studieværter Mohammed Nasser og Moataz Matar tilhører denne gruppe af egyptere, der mødtes i Istanbul efter 2013. De var begge aktive under den egyptiske opstand i $2011 \mathrm{og}$ forlod begge Egypten efter 2013 på grund af den politiske situation. Nasser havde arbejdet som manuskriptforfatter og tv-vært, men forsvandt fra de egyptiske medier efter åbenlyst at have kritiseret militærkuppet. I april 2014 dukkede han op på al-Sharq TV i Istanbul sammen med Matar. Matar havde været ansat på flere egyptiske tv-kanaler, bl.a. som sportskommentator. I 2013 var han i kort periode vært på Misr25, indtil den blev lukket efter kuppet. Begge studieværter har oplevet at være blevet kritiseret og udstillet af egyptiske medier, ligesom de begge er blevet stillet for retten $\mathrm{i}$ Egypten og dømt in absentia i flere sager. Ligesom andre aktivister har de oplevet, at familiemedlemmer i Egypten er blevet arresteret for at lægge pres på dem.

Matars og Nassers personlige historier er typiske for de eksilegyptere, der er engageret i regimekritiske medier. Der er adskillige ansatte på de regimekritiske kanaler i Istanbul, såvel som i London, som har forladt Egypten efter 2013 for at undgå politisk forfølgelse eller en fængselsdom. Den politiske aktivists nøglerolle i de regimekritiske medier er både en styrke og en svaghed. Den er en styrke, for så vidt at aktivisterne igennem deres egen historie garanterer ægtheden af den politiske opposition. De har villigt risikeret at miste deres levebrød og familie til gengæld for politisk forandring. På den anden side betyder mediekanalernes afhængighed af personer, der forlod Egypten af politiske årsager, at de ansatte i et vist omfang ingen professionel medieuddannelse har. En stor del af personalet består af unge, der forlod Egypten uden at have færdiggjort deres uddannelse eller var nyuddannede, da de forlod Egypten. Mange har derfor ingen erfaring inden for medieverdenen. Samtidig forstærkes problemet med ufaglært arbejde yderligere af mangel på tilstrækkelig finansiering, hvor medarbejdere fra tid til anden oplever uregelmæssige og reducerede lønninger. Den ustabile økonomi tvinger derudover kanalerne til at lukke, flytte eller konstant omlægge produktionen.

Nassers og Matars særstatus i denne sammenhæng viser sig ved deres reaktion på det politiske pres, der er opstået som følge af gryende, diplomatiske tilnærmelser mellem Egypten og Tyrkiet. Både Nasser og Matar har givet udtryk for, at de efter eget $\varnothing$ nske har besluttet at stoppe transmissionen af deres talkshows på henholdsvis Mekameleen TV og al-Sharq TV. Den 21. marts 2021, dvs. to dage efter afsløringen af mødet mellem de tyrkiske myndigheder og cheferne for de tre egyptiske tv-stationer i Istanbul, fortalte Nasser således i et interview på al-Jazeera alMasa'iya ${ }^{43}$ : «Lige nu undersøger jeg muligheden for at flytte enten til Canada eller UsA. Det er de eneste steder, som kan acceptere mig, som jeg er. Jeg accepterer ikke at være en ged i en stald. Jeg accepterer ikke, at jeg forlod Egypten for at søge frihed, for så at skulle acceptere de samme restriktioner et andet sted. Samtidig vil jeg ikke være årsagen til, at Tyrkiet underlægges yderligere pres. Som der står i Koranen: ‘Guds jord er stor', så jeg er fri til at tage til et andet land, som vil acceptere min frihed.»44 Den 10. april 2021 annoncerede Matar sin afgang i talkshowet på al-Sharq Tv: «Når jeg er færdig i dag, har jeg åben orlov fra mit hjem, alSharq TV. Det er ikke noget, jeg ville $\emptyset$ nske, men 
der er heller ikke nogen, der presser mig til det. Hverken Tyrkiet eller al-Sharq Tv. Men jeg vil ikke være årsagen til nogen som helst problemer for Tyrkiet eller Sharq TV. Jeg kommer tilbage til alSharq Tv uden invitation, når jeg har muligheden for at formidle sandheden, som jeg altid har gjort på al-Sharq TV.»45 Den 17. april relancerede Matar således nøjagtigt det samme program med samme navn og samme studie på sin egen YouTube-kanal. Sammenlignet med hans optræden på al-Sharq TV fremstår han endnu mere konfronterende og fokuserer nu ikke kun på Sisis regime, men kritiserer også andre arabiske regimer, især det saudiske og emiraternes regime. ${ }^{46}$ Den 4 . juni tilkendegiver Matar på sin YouTube kanal, at han og hans team helt forlader al-Sharq TV, men at han arbejder på et nyt projekt i samarbejde med en anden tv-station. ${ }^{47}$ I et videoklip uploadet på YouTube den 23. juni fortæller Matar om det pres, som de egyptiske tv-stationer i Tyrkiet har været underlagt siden marts 2021, og erkender, at han nu yderligere er blevet forbudt at sende sit program på sin YouTube-kanal eller udtale sig gennem andre sociale medier. ${ }^{48}$

Ind til midten af juni 2021 optræder Nasser til gengæld stadig med sit talkshow på Mekameleen TV. Det er svært at vurdere i hvilket omfang, hans kritik af Sisi er blevet dæmpet, men hans sprogbrug er modereret og ikke så vilkårligt som tidligere. Til gengæld fylder hans kritik af egyptiske embedsmænd i ministerier, politi og hær samt nyheder om Mellemøsten generelt mere. Han har på dette tidspunkt også stadig sin egen YouTubekanal. ${ }^{49}$ Herpå annoncerer han den 24. juni i et kort klip på 2 minutter og 30 sekunder, at han er blevet presset til at stoppe helt og heller ikke længere må optræde med sit budskab på enhver form for sociale medier. Nasser indleder indslaget med sætningen: «Vi siger ikke farvel, men vi ses», og understreger, at kampen ikke er slut..$^{\circ}$ Matar og Nasser er ikke de eneste egyptiske studieværter i
Istanbul, der har fået forbud mod at optræde i de sociale medier. Det gælder f.eks. også Hisham Abd Allah og Hamza Zaoba. ${ }^{51}$

Det er således lykkedes Egypten at stække Istanbulkanalernes regimekritik. Det er svært at forudsige, hvorvidt de kritiske stemmer også er stoppet, eller om de er i stand til at finde nye platforme for kritik. Man kan diskutere, hvorvidt en evt. flytning til sociale medier uden for Tyrkiet vil have den samme gennemslagskraft. På den ene side ville eksilaktivisterne dermed fratages den institutionelle beskyttelse og finansiering tillige med et publikum, der har set kanalerne af varierende grunde, ${ }^{52}$ og derfor ikke automatisk vil følge aktivister som Nasser og Matar over på f.eks. YouTube. På den anden side kunne de via sociale medier potentielt nå et andet og måske mere politisk dedikeret publikum. Det ville dog betyde, at de omtalte kritikere bosatte sig i et andet land end Tyrkiet.

\section{Konklusion}

Al-Watan Tv, al-Sharq TV og Mekameleen TV er sammen med andre regimekritiske medier i Istanbul grundlæggende baseret på opfattelsen af, at det nuværende egyptiske regime er illegitimt. De har derfor ikke overraskende været en kilde til frustration hos et egyptisk regime, som har valgt en politisk fremgangsmåde, der ikke accepterer opposition. Det er en sådan opposition, Istanbulkanalerne med en vis succes har repræsenteret gennem alternative narrativer om den politiske situation i Egypten og ved at mobilisere alliancer $i$ form af den tyrkiske stat, finansierer og borgerjournalister. Hvorvidt kanalerne er lykkedes med at mobilisere egentlig politisk modstand blandt seere i og uden for Egypten er mere uklart. Selv om kanalernes mediering af konflikten bliver omdrejningspunktet for mediebrugernes brug af dem og en måde for diasporaen at opretholde forbindelse til oprindelseslandet, ${ }^{53}$ giver egyptiske seere fra 
forskellige europæiske lande udtryk for ambivalente opfattelser af kanalernes virkemidler. ${ }^{54} \mathrm{De}$ mest politisk engagerede synes, at kanalernes journalistiske niveau er for lavt, mens de mindre politisk engagerede udtrykker fascination af kanalernes konfronterende, overdrevne og sarkastiske stil. De forskellige seerreaktioner tyder på en politisk mobilisering, der snarere er flygtig end velorganiseret. 55

Kanalernes relative succes er samtidig under pres ikke bare gennem aftalen mellem Tyrkiet og Egypten, men også gennem Egyptens fors $\emptyset \mathrm{g}$ på for det første at dæmonisere kanalerne ved at betegne dem alle som talerør for Det Muslimske Broderskab. For det andet ved at tilbageholde eller fængsle mediepersonels familiemedlemmer i Egypten. I forlængelse heraf kan man stille spørgsmålet, hvilke konsekvenser det vil få for kanalernes alternative narrativ, at populære, liberale talkshowsværter som Mohammed Nasser på Mekameleen TV og Moataz Matar på al-Sharq Tv, som resultat af Egyptens pres på Tyrkiet, enten har trukket sig fra eller modereret deres kritik i kanalerne. Selv om Nasser i interviewet med al-Jazeera udtaler, at det er udtryk for kanalernes succes, at de er blevet et centralt omdrejningspunkt for fremsættelse af krav mellem to så store lande som Egypten og Tyrkiet, er spørgsmålet, hvad de har kunnet og kan bruge succesen til fremadrettet.

$$
\cdot f \cdot
$$

1 youtube.com/watch?v=j8jw-WF11AM (set d. 7. maj 2021).

2 youtube.com/watch?v=IPfCv-Ob-EE (set d. 3. maj 2021) og youtube.com/watch?v=9sopLs2Z-P4 (set d. 3 . maj 2021).

3 Al-Araby al-Jadid, «'Al-Mirsid al-Araby’ yohazir min tahdidaat al-Sisi lil I’laam al-Mu'arid bi al-Kharij», AlAraby al-Jadid, 18. maj 2018.

4 youtube.com/watch?v=WB9MVTRo2YE (set d. 15. april 2021) og youtube.com/watch?v=XFdWGrGgNqM (set d. 30. april 2021).
5 Fatima El Issawi, «Egyptian media under transition: In the name of the regime... In the name of the people?» (London: POLIS, Department of Media and Communications, London School of Economics, 2014), 48 \& 61-67; Reporters without Borders, «Egypt. Sisification of the Media - a Hostile Takeover», Media Ownership Monitor (blog), set 12. maj 2021, mom-rsf.org/en/countries/egypt/.

6 youtube.com/watch?v=hZUNa3Qyv3o (set d. 3. maj 2021); youtube.com/watch?v=YtDBo6Js5R8 (set d. 7 . maj 2021).

7 almasryalyoum.com/news/details/495094 (set d. 1. maj 2021).

8 Mohammed Alrmizan, «Arab Diasporic Media in Turkey: A Story of (Trans)National Narratives in the Middle East», Text (Intellect, 1. april 2021), doi.org/10.1386/ajms-0oo37-1.

9 Fiona B. Adamson, «Mobilizing for the transformation of home: politicized identities and transnational practices», i New Approaches to Migration? Transnational Communities and the Transformation of Home, red. Nadje AlAli og Khalid Koser (London: Routledge, 2002), 165-78.

10 Se f.eks. Rasha Abdulla, «Egypt's Media in the Midst of Revolution» (Washington DC: Carnegie Endowment for International Peace, 2014); Mohammed El-Nawawy og Sahar Khamis, Egyptian revolution 2.o: Political blogging, civic engagement, and citizen journalism (New York: Palgrave Macmillan, 2016); Linda Herrera, Revolution in the age of social media: The Egyptian popular insurrection and the Internet (Verso Trade, 2014); Philip N. Howard og Muzammil M. Hussain, Democracy's fourth wave?: digital media and the Arab Spring (Oxford: Oxford University Press, 2013); Carola Richter, «The Egyptian Muslim Brotherhood movement and its media strategies: The mobilising effect of religion in contentious politics», Actors in the public sphere: Means, objectives, and effects, 2011, 167-91.

11 Rua Al-sheikh og Namir Al-nuaimi, «The Role of the Media Among Egyptian Diaspora in the UK During the 2011 Egyptian Uprising and Afterwards», management 93 (2020); Isık Kuscu, «The Egyptian American diaspora during and in the aftermath of the Egyptian revolution of 2011», Ortado?u Etütleri 4, nr. 1 (2012): 121-42; Lea Müller-Funk, «Diaspora mobilizations in the Egyptian (post) revolutionary process: Comparing transnational political participation in Paris and Vienna», Journal of Immigrant \& Refugee Studies 14, nr. 3 (2016): 353-70; Lea Müller-Funk, Egyptian Diaspora Activism During the Arab Uprisings: Insights from Paris and Vienna (Routledge, 2018).

12 Mostafa Shehata, «Political participation and power relations in Egypt: The scope of newspapers and social network sites», Media and Communication 5, nr. 2 (2017): 53-63; Mostafa Shehata, «Newspapers and Social Network Sites in Egypt After the 2011 Revolution: Connective Action, Communication Power and Mediatization of Politics» (PhD thesis, Roskilde, Roskilde University, 2018). 
13 Carola Richter, “«Mobilise, Justify, Accuse: The Egyptian Muslim Brotherhood and Changing Media Practices», i Media Practices, Social Movements, and Performativity (Routledge, 2017), 100-113.

14 Sahar Khamis og Randall Fowler, «Arab resistance in the diaspora: Comparing the Saudi dissident and the Egyptian whistleblower», Journal of Arab \& Muslim Media Research 13, nr. 1 (2020): 31-49.

15 Stig Hjarvard, Mette Mortensen, og Mikkel Fugl Eskjær, «Introduction: Three dynamics of mediatized conflicts», i The dynamics of mediatized conflicts (Peter Lang, 2015), 9.

16 Myria Georgiou, «Media, Diaspora, and the Transnational Context», The handbook of global media research, 2012, 365-80.

17 Adamson, «Mobilizing for the transformation of home: politicized identities and transnational practices».

18 Peggy Levitt og Nina Glick Schiller, «Conceptualizing simultaneity: a transnational social field perspective on society», International migration review 38, nr. 3 (2004): 1002-39.

19 Vered Amit og Nigel Rapport, The trouble with community: anthropological reflections on movement, identity and collectivity (London: Pluto Press, 2002), 60.

20 Aihwa Ong, «Cyberpublics and diaspora politics among transnational Chinese», Interventions 5, nr. 1 (2003): 82-100.

21 Naomi Sakr, «Social Media, Television Talk Shows, and Political Change in Egypt», Television \& New Media 14, nr. 4(2013): 322-37, doi.org/10.1177/1527476412463446.

22 Nina Grønlykke Mollerup og Sherief Gaber, «Making media public: On revolutionary street screenings in Egypt», International Journal of Communication 9 (2015): 19; Courtney C. Radsch, Cyberactivism and citizen journalism in Egypt (New York: Springer, 2016); Mark R. Westmoreland, «Street Scenes: the politics of revolutionary video in Egypt», Visual Anthropology 29, nr. 3 (2016): 243-62.

23 Ehab Galal, «Offentligheder og forandring i studier af arabiske medier», Babylon. Nordisk tidsskrift for Midtøstenstudier, nr. 1 (2017).

24 Ehab Galal, «Ringfenced religion? Egypt's religious media between faith and politics», i Routledge Handbook of Contemporary Egypt, red. Robert Springborg m.fl. (London: Routledge, 2021), 435-45.

25 Killian Clarke, «Saying 'Enough': Authoritarianism and Egypt's Kefaya Movement», Mobilization: An International Quarterly 16, nr. 4 (2011): 397-416; Sherif Mansour, «Enough is not enough: Achievements and shortcomings of Kefaya, the Egyptian movement for change», i Civilian Jihad (Springer, 2009), 205-18; Ali Sonay, Making Revolution in Egypt: The 6 April Youth
Movement in a Global Context (London: Bloomsbury Publishing, 2018).

26 egypt.mom-rsf.org/en/context/law/regulatoryauthorities/ (set d. 15. maj 2021).

27 Ehab Galal, «Qatar: A Small Country with a Global Outlook», i Arab Media Systems, red. Carola Richter og Claudia Kozman, bd. 3, Global Communications (Cambridge: Open Book Publishers, 2021), 127-43.

28 Alrmizan, «Arab Diasporic Media in Turkey».

29 Mada Masr, «Egyptian officials: 3 demands for rapprochement with Turkey in ongoing talks», Mada Masr, 4. maj 2021, madamasr.com/en/2021/05/04/news/ u/egyptian-officials-3-demands-for-rapprochementwith-turkey-in-ongoing-talks/; Haisam Hassanein, «Egypt-Turkey Rapprochement Is Constraining the Muslim Brotherhood», The Washington Institute for Near East Policy (blog), 30. marts 2021, washingtoninstitute.org/policy-analysis/egypt-turkeyrapprochement-constraining-muslim-brotherhood. (begge læst d. 12. maj 2021).

30 Middle East Online, "Turkey asks Islamist-leaning Egyptian TV channels to tone down criticism”, Middle East Online MEO, 19. marts 2021, middle-eastonline.com/en/turkey-asks-islamist-leaning-egyptiantv-channels-tone-down-criticism\#off-canvas.

31 youtube.com/watch?v=qBI7DsUDEl8 (set d. 18 . marts 2021).

32 youtube.com/watch?v=eK5 P6-WU-oE (set d. 9. maj 2021) og youtube.com/watch?v=msKhUfE 3 Noc (set d. 16. januar 2021).

33 Mada Masr, «Egyptian officials: 3 demands for rapprochement with Turkey in ongoing talks».

34 youtube.com/watch?v=PiFKAWmgRlo (set d. 7 . maj 2021).

35 Islam Halayiqa, «Al-ielam alearabi fi turkia al-Imkanat wa Al-Tahadiyat wa Al-Waqie (Arabiske medier i Tyrkiet: Potentiale, udfordringer og virkelighed)» (Al-Muasasa Al-Arabiya lil-Dirasat Al-Iistratijia, 2020), 18-19.

36 Se mere om islamisk tv i Galal, «Ringfenced religion? Egypt's religious media between faith and politics».

37 Mette Mortensen, «Medialiseret konflikt: Globalisering, professionalisering og digitalisering», i MedialiseringMediernes rolle $i$ social og kulturel forandring, red. Stig Hjarvard (København: Hans Reitzels Forlag, 2016), 21739.

38 Ehab Galal, «Where has the authority gone? New imperatives and audience research», i Arab TV Audiences: Negotiating Religion and Identity, red. Ehab Galal (Frankfurt: Peter Lang, 2014), 11.

39 Adamson, «Mobilizing for the transformation of home: politicized identities and transnational practices». 
40 Michele Dunne og Amr Hamzawy, Egypt's Political Exiles: Going Anywhere but Home (Carnegie Endowment for International Peace, 2019).

41 Dunne og Hamzawy, 1.

42 Dunne og Hamzawy.

43 Al-Jazeera Masa'iya er en af al-Jazeeras kanaler, der sender om aftenen (Masa'iya betyder aften), hvor dagens vigtigste emner diskuteres.

44 youtube.com/watch?v=GPhvb9-ricU (set 12. maj 2021).

45 youtube.com/watch?v=2RaeUA5oQVs (set 20. juni 2021).

46 Matars YouTube-kanal.

47 youtube.com/watch?v=ZLibpITMig4 (set 4. juni 2021).

48 youtube.com/watch?v=NXwupldF690\&t=27s (set 4 . juli 2021).

49 Mohammed Nassers YouTube-kanal.

50 youtube.com/watch?v=qU34bR8SILI\& $\mathrm{t}=6 \mathrm{sr}$ (set 4 . juli 2021).

51 almasryalyoum.com/news/details/2361129 (set den 4 . juli 2021).

52 Jeg har i forbindelse med herværende forskningsprojekt interviewet egyptiske mediebrugere i Tyrkiet og i ni europæiske lande.

53 Magnus Andersson, «Media and Migration through the Lens of Mediatization and Transnationalism», $\mathrm{i}$ Communication and Community: The annual ICA Conference, Phoenix (2012), 2012.

54 Om disse interviews, se note 49.

55 W. Lance Bennett og Alexandra Segerberg, The logic of connective action: Digital media and the personalization of contentious politics (Cambridge: Cambridge University Press, 2013). 